Creative commons User License: CC BY-NC-ND

Abstracted by: EBSCOhost, Electronic Journals Service (EJS),

Google Scholar, Directory of Open Access Journals (DOAJ),

Journal Seek, Scientific Commons,

Food and Agricultural Organization (FAO), CABI and Scopus
Journal of Agricultural Extension

Vol. 21 (3) October, 2017

ISSN(e): 24086851; ISSN(Print); 1119944X

http://journal.aesonnigeria.org

http://www.ajol.info/index.php/jae

Email: editorinchief@aesonnigeria.org

\title{
Bio-Security Measures Employed by Poultry Farmers in Enugu State Nigeria
}

https://dx.doi.org/10.4314/jae.v21i3.9

\section{Eze, C.O.}

Department of Agricultural Extension, Faculty of Agriculture,

University of Nigeria, Nsukka

Chah, J.M.

Department of Agricultural Extension, Faculty of Agriculture, University of Nigeria, Nsukka

jane.chah@unn.edu.ng

$+2348032420600$

Uddin, I.O.

Department of Agricultural Extension, Faculty of Agriculture, University of Nigeria, Nsukka uddinirenonsen@gmail.com +2347036842083

\section{Anugwa, I.J.}

Department of Agricultural Extension, Faculty of Agriculture, University of Nigeria, Nsukka

ifeoma.irohibe@unn.edu.ng

+2348065435735

\section{Igbokwe, E.M.}

Department of Agricultural Extension, Faculty of Agriculture, University of Nigeria, Nsukka edwin.igbokwe@unn.edu.ng $+2348034261915$

\section{Abstract}

This study ascertained biosecurity measures used by poultry farmers in Enugu State, Nigeria. Multistage sampling technique was used to select 120 poultry farmers. Descriptive statistics and multiple regression analysis were used to analyse data and present results for the study. The mean age of respondents was 47 years while farming experience was 9.6 years. Almost all (97.5\%) the respondents had one form of formal education. The majority of the farmers sourced biosecurity information from co-poultry farmers (87.7\%) and veterinary officers (81.4\%). Major bio-security measures used by farmers include: inspection of flock daily to pick mortalities $(\bar{x}=3.7)$, isolation and quarantine of sick birds ( $\bar{x}=3.7)$, vaccination of birds $(\bar{x}=3.6)$, as well as adequate cleaning of feeding and drinking troughs $(\bar{x}=3.6)$. The standardized coefficients for age (0.327), farming experience (0.278) and farm income $(0.409)$ had a positive influence $\left({ }^{*} P \leq 0.05\right)$ on use of biosecurity measures. Use of battery cage system $(p=0.013)$ and use of 
Creative commons User License: CC BY-NC-ND

Abstracted by: EBSCOhost, Electronic Journals Service (EJS),

Google Scholar, Directory of Open Access Journals (DOAJ),

Journal Seek, Scientific Commons,

Food and Agricultural Organization (FAO), CABI and Scopus
Journal of Agricultural Extension

Vol. 21 (3) October, 2017

ISSN(e): 24086851; ISSN(Print); 1119944X

http://journal.aesonnigeria.org

http://www.ajol.info/index.php/jae

Email: editorinchief@aesonnigeria.org

deep litter combined with battery cage systems ( $p=0.001)$ had a negative influence on the use of biosecurity practices. Extension workers should educate farmers on the importance and use of biosecurity measures for optimum production.

Keywords: Vaccination, Quarantine practices, Veterinary officers, Bio-Security, Poultry Farmers

\section{Introduction}

In Nigeria, small scale poultry represents $85 \%$ of the estimated 82 million adult chickens, accounting for approximately 94 percent of total poultry keeping and nearly 4 percent of the total estimated value of the livestock resources in the country (Gueye, 2000). Poultry production is the most efficient and cost-effective way of increasing the availability of high-protein food, as eggs are known to provide the most perfectly balanced food containing all the essential amino acids, minerals and vitamins (Branckeart et al., 2000). Production of poultry birds and eggs occupies a prime position for improving animal protein consumption of both rural and urban households in Nigeria. In view of this, programmes and projects have been established by different tiers of government to enhance farmers' agricultural production. In spite of this, food security, improved livelihood and attainment of selfsufficiency in food production has remained a delusion in Nigeria. According to FAO reports, Nigeria has low animal protein intake with an average of $6 \mathrm{~g}$ per head per day while the world average is $34 \mathrm{~g}$ per head per day (FAO, 2010). The report further asserted that animal protein constitutes only $3 \%$ of an average Nigerian meal, as against $12 \%$ recommended for healthy living.

Diseases remain one of the major threats to boosting poultry production in Nigeria (Adewole, 2012). The major diseases are the newcastle disease, avian influenza, avian pox, infectious bursal disease, colisepticeamia, coccidiosis and worm infestation (Usman and Diarra, 2008) with newcastle disease being the most recognized by poultry farmers (Adene and Oguntade, 2006). Disease reduces the productivity of a sick animal and causes decline in output, increases cost of production and reduction in profit (Farooq et al., 2000). Mohamadou et al. (2010) estimated an annual economic financial burden of livestock diseases to the tune of A29.2 billion in Nigeria. Also, economic losses experienced by poultry farmers for the years 2009-2011 amounted to over three billion Naira due to infectious bursal disease outbreak alone (Musa et al., 2012). Use of vaccines, good hygiene, increasing standards of cleanliness and regular monitoring of flock health programmes have enormous contributions to the establishment of flock with a low disease incidence. This type of programme in any livestock farming is known as biosecurity.

Biosecurity refers to all the management practices aimed at excluding or reducing the potential for the transmission and spread of diseases to animals, humans or an area initially free from the disease-causing agents (Halifa, 2008). Strict biosecurity measures, in addition to vaccinations, are strategic prevention and control policies adopted to control some contagious poultry diseases as vaccination alone is not enough to control them under field conditions (Abdu, 2007). Good husbandry practices such as adequate feeding, housing and stocking to avoid overcrowding, 
Creative commons User License: CC BY-NC-ND

Abstracted by: EBSCOhost, Electronic Journals Service (EJS),

Google Scholar, Directory of Open Access Journals (DOAJ),

Journal Seek, Scientific Commons,

Food and Agricultural Organization (FAO), CABI and Scopus
Journal of Agricultural Extension

Vol. 21 (3) October, 2017

ISSN(e): 24086851; ISSN(Print); $1119944 X$

http://journal.aesonnigeria.org

http://www.ajol.info/index.php/jae

Email: editorinchief@aesonnigeria.org

good ventilation, proper disposal of wastes, cleaning and disinfection of poultry premises help to keep out infections and their spread (Jordan, 1990; Ameji et al., 2012). To avert human health risks and economic losses, biosecurity measures are inevitable in farms through isolation, limiting number of visitors coming into the farm and/or sanitation measures.

Poor or absent of biosecurity practices in farms results in high levels of baseline mortality due to predators (e.g. rodents, snakes, small carnivores) or infectious diseases (e.g. Newcastle Disease (ND), salmonellosis, Gumboro disease or fowl typhoid) (Sonaiya \& Swan, 2004; Badubi et al. 2004; Abdelqader et al., 2007; Biswas et al., 2008; Bell, 2009; Ison et al., 2012).

Initially vaccination was one of the methods in controlling poultry diseases. Unfortunately, there has been high vaccination failure partly because of poor storage due to epileptic nature of electricity supply in Nigeria. Therefore, the only alternative measure to control diseases is an effective biosecurity programme. This study therefore sought to ascertain biosecurity measures employed by small scale poultry farmers in Enugu State, Nigeria. Specifically, the study sought to: describe respondents' socioeconomic characteristics; ascertain sources of information on biosecurity measures practiced; and ascertain biosecurity measures practiced by farmers.

The hypothesis of the study was stated in the null form as follows:

$\mathrm{Ho}_{1}$ : there is no significant influence of socioeconomic characteristics of farmers on the biosecurity measures practiced.

\section{Methodology}

The study was conducted in Enugu State, Nigeria. The State lies between latitudes $5^{\circ} 56^{1}$ North and $7^{\circ} 06^{1}$ North of the equator and longitudes $6^{\circ} 53^{1}$ East and $7^{\circ} 55^{1}$ East of the Greenwich meridian. The state is bounded in the North by Kogi and Benue States, in the East by Ebonyi State, in the South by Abia and Imo States and in the West by Anambra State (Ezike, 1998).

A multistage sampling technique was used in the selection of poultry farmers. The first stage involved purposive selection of two agricultural zones (Enugu and Nsukka) out of the six in the state. The two zones have the highest number of poultry farms in the state. In the second stage, two blocks were selected from each zone using simple random sampling technique. In the third stage, two circles were selected from each block using simple random sampling technique. This gave a total of four circles per zone and a total of eight circles in the state. In the fourth stage, a list of registered poultry farmers for each selected circle was obtained from the Poultry Farmers Association of Nigeria while a list of unregistered members was compiled with the assistance of Zonal Extension Officers. The lists were pooled together and from it, 15 farmers were selected through simple random sampling technique. Thus, the total sample size for the study was 120 respondents.

Data for the study were collected using a semi-structured interview schedule. Poultry farmers were interviewed with the aid of key informants. The following socioeconomic characteristics were considered: age, sex, marital status, farming experience, educational level, average years spent in school, membership of social organization, farm income, source of credit, household size, flock size and poultry management systems. 
Creative commons User License: CC BY-NC-ND

Abstracted by: EBSCOhost, Electronic Journals Service (EJS), Google Scholar, Directory of Open Access Journals (DOAJ), Journal Seek, Scientific Commons,

Food and Agricultural Organization (FAO), CABI and Scopus
Journal of Agricultural Extension

Vol. 21 (3) October, 2017

ISSN(e): 24086851; ISSN(Print); 1119944X

http://journal.aesonnigeria.org

http://www.ajol.info/index.php/iae

Email: editorinchief@aesonnigeria.org

Respondents were presented with a list of twenty-six (26) possible biosecurity measures and were requested to indicate whether or not they practice/use the biosecurity measures. They were also asked to specify biosecurity measures used that were not included in the list. Each biosecurity measure practiced/used by respondents was scored 1, while each biosecurity not practiced/used by the respondents was scored 0 . The total score for each biosecurity measure was converted to percentage and a score of greater than or equal to $80 \%$ was regarded as very highly used biosecurity measure, $60-79 \%$ as highly used, $40-59 \%$ as moderately used, $20-39 \%$ as fairly used/practiced, and $19 \%$ or below was regarded as poorly used biosecurity measure (a modification of classification of Iliyasu, Kabir and Galabanci, 2005).

To ascertain the source of information on biosecurity measures among farmers, possible source of information on biosecurity were presented for respondents to choose from the options available to them. They were also asked to add other sources they get information on biosecurity not available on the list.

Percentage, mean and standard deviation were used in the presentation of results. Hypothesis for the study was analysed using multiple regression. The regression equation was:

$$
\begin{aligned}
& Y=\alpha+\beta_{1} X_{1}+\beta_{2} X_{2}+\beta_{3} X_{3}+\beta_{4} X_{4}+\beta_{5} X_{5}+\beta_{6} X_{6}+\beta_{7} X_{7}+\ldots \ldots \ldots+U \\
& \text { Where } y=\text { Total score } \\
& \alpha=\text { constant term } \\
& \beta_{1}-\beta_{5}=\text { represents coefficients } \\
& X_{1}=\text { age (in years) } \\
& X_{2}=\text { sex (male }=1, \text { female }=0 \text { ) } \\
& X_{3}=\text { farming experience (in years) } \\
& X_{4}=\text { years spent in school } \\
& X_{5}=\text { Membership of social organization (group member }=1 \text {, Not a } \\
& X_{6}=\text { Farm income (per annum) } \\
& X_{7}=\text { Source of credit (savings }=1 \text {, credit }=0 \text { ) } \\
& X_{8}=\text { Household size (no of persons eating from the same pot) } \\
& X_{9}=\text { Flock size (no birds in the farm) } \\
& X_{10}=\text { System of poultry farming (deep litter }=1, \text { battery cage }=2, \text { both }=3 \text { ) } \\
& U=\text { Error term }
\end{aligned}
$$

Data generated from the interview were analysed using Statistical Product and Service Solutions (SPSS) version 16 at $5 \%$ level of probability.

\section{Results and Discussion}

\section{Socio-economic Characteristics of Poultry Farmers}

Table 1 presents socio-economic characteristics of the poultry farmers. The average age of respondents was 47 years. Fifty-seven percent of the respondents were male while $86 \%$ were married. The majority $(95 \%)$ of the respondents were literate with average years spent in school being 13. Sixty-three percent of the farmers belonged to social organizations. The mean annual income was $₫ 3,941,437.29$. The mean 
Creative commons User License: CC BY-NC-ND

Abstracted by: EBSCOhost, Electronic Journals Service (EJS), Google Scholar, Directory of Open Access Journals (DOAJ), Journal Seek, Scientific Commons,

Food and Agricultural Organization (FAO), CABI and Scopus
Journal of Agricultural Extension

Vol. 21 (3) October, 2017

ISSN(e): 24086851; ISSN(Print); $1119944 X$

http://journal.aesonnigeria.org

http://www.ajol.info/index.php/jae

Email: editorinchief@aesonnigeria.org

household size was 8 persons. About $43 \%$ of the respondents raised their birds on deep litter and the mean flock size was 4,795 birds.

Table 1: Socioeconomic characteristics of respondents

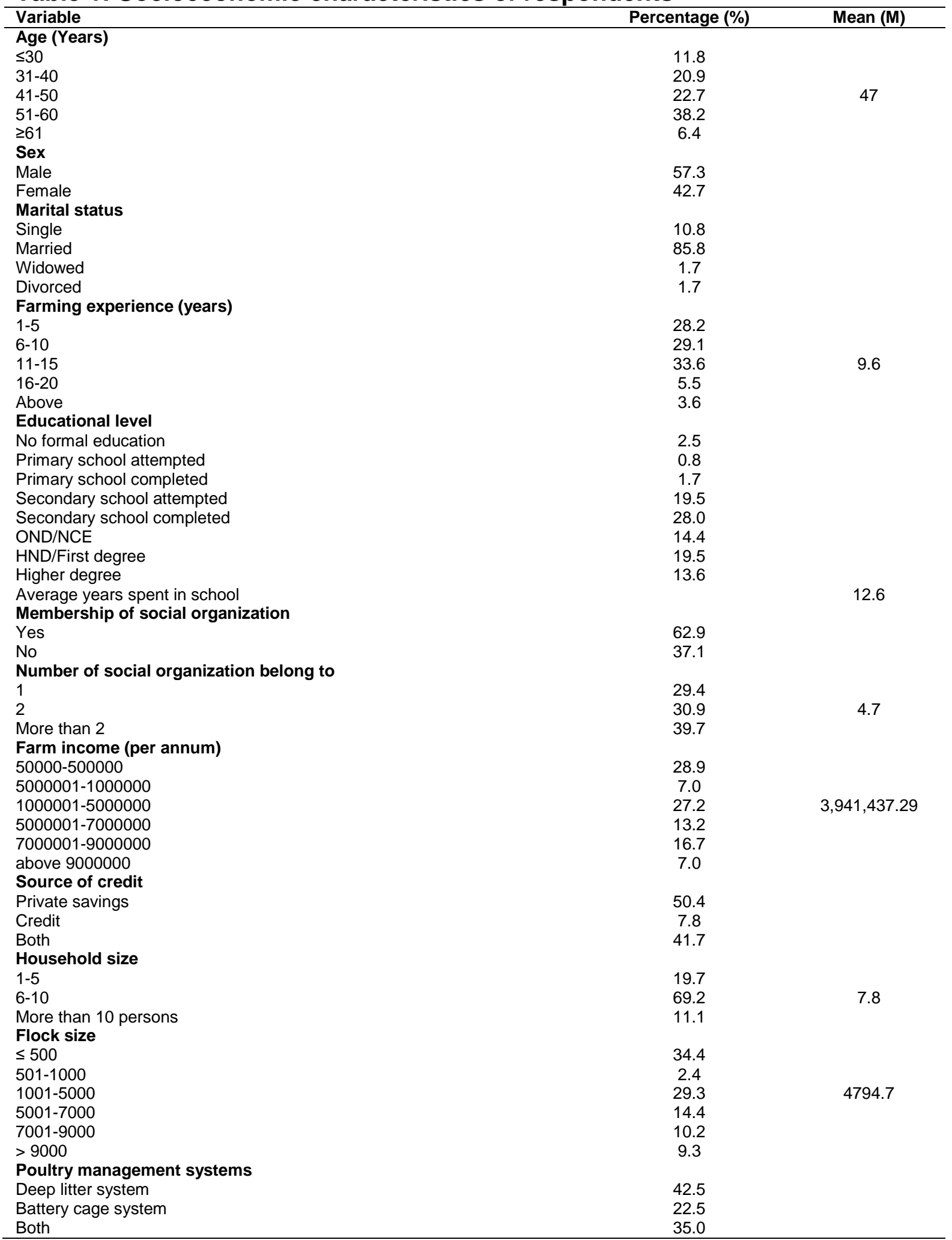

Source: Field Survey, 2015; 1 Naira = 195 USD 
Creative commons User License: CC BY-NC-ND

Abstracted by: EBSCOhost, Electronic Journals Service (EJS),

Google Scholar, Directory of Open Access Journals (DOAJ),

Journal Seek, Scientific Commons,

Food and Agricultural Organization (FAO), CABI and Scopus
Journal of Agricultural Extension

Vol. 21 (3) October, 2017

ISSN(e): 24086851; ISSN(Print); 1119944X

http://journal.aesonnigeria.org

http://www.ajol.info/index.php/iae

Email: editorinchief@aesonnigeria.org

The average age of the respondents was 47 years, indicating that they were still in their active and productive age. Poultry farming is labour intensive and requires young farmers to cope with the robust biosecurity practices including disease management. This may be one of the reasons why almost all the farmers practice biosecurity in their farms. Poultry farming in the study area is dominated by males. This is similar to the study of Maikasuwa and Jabo (2011) in Sokoto, and Uzokwe and Bakare (2013) in Ose Local Government Area of Ondo State, Nigeria, who reported that the majority of poultry farmers in their studies where male. This may be because poultry farming is labour intensive and so scare women out of the venture. Also, males are bread winners in the family and have to engage in productive activities to provide for the needs of the family. The marital status of famers has a direct implication on the household size and subsequently on the availability of family labour to assist on the farm. Most poultry farmers in the study were literate. High level of education help farmers to embrace innovations and ideas relating to biosecurity practices. Asfaw and Admassie (2004); Bamire, Fabiyi and Manyong (2002) reported that education affects agricultural productivity by enhancing the capacity of farmers to obtain and analyse information which may result to increased production from given resources. This goes further to show that poultry farming is taken up by people who can read and write as such could follow prescriptions written on poultry drugs, vaccines and feeds. If more educated minds engage in this venture it will help improve the effective use of biosecurity measures.

Social affiliation/relationship is very evident in most social systems (rural or urban). Farmers use this avenue to interact and obtain information on events in their locality. Belonging to social organizations help farmers to satisfy their innate need of solving their problems through collective efforts (Ekong, 2010). Hence, a good avenue to enlighten farmers on recent trends as it deals with biosecurity measures in their farms. Farmers in the area earn an appreciable amount of income per year. High income is very crucial for farmers to strictly adhere to biosecurity measures as well as to ensure hygienic poultry production that can pave way for better income and sustainable development.

The household size of the respondents is above national average of 5 persons in rural Nigeria (NBS, 2009). This large household size may be an advantage in the use of family labour for poultry management but brings about intense competition for limited household resources and food resources (Uddin et al., 2015). Deep lither system of poultry management which is used by the majority of the farmers could discourage commercial layers rearing. In the deep litter system, chickens have direct access to their faeces. This translates to increased risk of infection and high medication costs, increasing the overall cost of production. Floor birds that have direct access to their faeces, picking up their faeces with food as well as ammonia, can constitute serious health risks. In the battery cage system, the droppings drop on the floor beneath the cages so the chickens have no direct contact with their faeces. This reduces health risks and lead to much less expenditure on vaccines (Ayadole, 2016, Duncan, 2001). Also, regular cleaning of deep litter is required. This may increase the cost of production of the birds and reduce profits. However, a farmer needs economic survey to be able to ascertain the profitability and relevance of each rearing system with special consideration of climatic conditions. 
Creative commons User License: CC BY-NC-ND

Abstracted by: EBSCOhost, Electronic Journals Service (EJS),

Google Scholar, Directory of Open Access Journals (DOAJ),

Journal Seek, Scientific Commons,

Food and Agricultural Organization (FAO), CABI and Scopus
Journal of Agricultural Extension

Vol. 21 (3) October, 2017

ISSN(e): 24086851; ISSN(Print); 1119944X

http://journal.aesonnigeria.org

http://www.ajol.info/index.php/jae

Email: editorinchief@aesonnigeria.org

\section{Sources of Information on Biosecurity Measures}

The respondents obtained information on biosecurity measures from multiple sources (Table 2). However, the principal sources of information were co-poultry farmers $(87.7 \%)$, veterinary officers $(81.4 \%)$, textbooks $(75.9 \%)$ and Internet $(70.9 \%)$.

Table 2: Sources of information on biosecurity practices

\begin{tabular}{lc}
\hline Source of information & Percentage (\%) \\
\hline Co-poultry farmers & 87.7 \\
Veterinary officers & 81.4 \\
Textbooks & 75.9 \\
Internet & 70.9 \\
Radio & 68.4 \\
Newspapers & 68.1 \\
Leaflets & 66.4 \\
Extension agents/ministry of agriculture & 65.8 \\
Magazines & 64.7 \\
Pamphlets & 64.0 \\
Television & 63.8 \\
Posters & 56.1 \\
Films/video & 36.8 \\
Marketers of poultry products & 36.0 \\
Friends and neighbours & 33.9 \\
Audio cassettes & 24.2 \\
Town criers (local way of passing on information to & 21.7 \\
farmers) &
\end{tabular}

*Multiple responses

Poultry farmers in the study area had a strong network of communication with which they could reach out to themselves. This goes further to buttress the reason why membership of social organization had significant influence on the use of biosecurity. Respondents' use of textbooks and the internet is quite remarkable. This may not be unconnected with the level of literacy observed among respondents in Table 1. Audio cassettes are gradually getting outdated because of recent technological innovations while the use of town criers (local means of disseminating information in the community) may not have been so effective as a result of the gradual development and urbanization of the zones where this study was carried out and the presence of many local radio stations. Nonetheless, they remain useful medium to communicate information to farmers on biosecurity measures.

With farmers in the study having access to information on biosecurity practices from different sources, a balance in knowledge might have been achieved. This may enhance the farmers' ability to make sound decision on matters regarding biosecurity in their farms. Maningas et al. (2005) opines that information in the hands of the farmers means empowerment through control over their resources and decision- 
Creative commons User License: CC BY-NC-ND

Abstracted by: EBSCOhost, Electronic Journals Service (EJS),

Google Scholar, Directory of Open Access Journals (DOAJ),

Journal Seek, Scientific Commons,

Food and Agricultural Organization (FAO), CABI and Scopus
Journal of Agricultural Extension

Vol. 21 (3) October, 2017

ISSN(e): 24086851; ISSN(Print); $1119944 X$

http://journal.aesonnigeria.org

http://www.ajol.info/index.php/jae

Email: editorinchief@aesonnigeria.org

making processes. They noted that an effective and efficient delivery system of essential information and technology services facilitates the clients' critical role in decision-making towards improved agricultural production, processing, trading, and marketing. This is further buttressed by Food and Agriculture Organization (2005) that information is very important for rural development. In achieving this, there is a need to focus on human resources for increased knowledge and information sharing about agricultural production, as well as on appropriate communication methodologies, channels and tools (Vidanapathirana, 2012).

\section{Biosecurity measures practiced by farmers}

All the respondents indicated a very high use of biosecurity measures as shown in Table 3.

Table 3: Biosecurity measures used

\begin{tabular}{lc}
\hline Biosecurity measures & Percentage \\
\hline Restraining of visitors into the farm & 97.5 \\
Farmers/farm workers should limit visits to other farms & 99.1 \\
Keeping other animals out of poultry house & 98.3 \\
Sound rodent and pest control programme & 96.7 \\
Avoiding contact with local, wild/migratory birds & 99.1 \\
Inspecting flocks daily & 99.1 \\
Isolating and quarantining sick birds & 99.1 \\
Keeping birds of different ages separately & 98.3 \\
Selling crates along with eggs & 95.0 \\
No recycling of feed bags & 95.0 \\
Providing foot-dip with disinfectant & 98.3 \\
Providing protective clothing & 99.1 \\
Regular and proper washing and disinfection & 98.3 \\
Providing good ventilation in the poultry house & 99.1 \\
Constant cleaning of litter & 98.3 \\
Regular removal and proper disposal of dead birds & 95.8 \\
Keeping areas around poultry house and feed bins clean to keep & 98.3 \\
away rodents & \\
Recognizing disease sign and reporting to veterinarians & 98.3 \\
Adequate floor spacing & 99.1 \\
Adequate feeding and drinking troughs & 99.1 \\
Fumigate poultry house and equipments & 96.7 \\
Separate transport for eggs and birds & 97.5 \\
Wash hands before and after handling poultry & 99.1 \\
Availability of laying nests & 97.5 \\
Vaccination of birds & 98.3 \\
\hline
\end{tabular}

Although all the farmers used biosecurity measures in farms, observations show that strict measures were not applied in their use (for example some visitors were allowed in the farm without using the dip). This improper practice of biosecurity measures observed may be due to farmers' lack of adequate knowledge, resources 
Creative commons User License: CC BY-NC-ND

Abstracted by: EBSCOhost, Electronic Journals Service (EJS), Google Scholar, Directory of Open Access Journals (DOAJ), Journal Seek, Scientific Commons,

Food and Agricultural Organization (FAO), CABI and Scopus
Journal of Agricultural Extension

Vol. 21 (3) October, 2017

ISSN(e): 24086851; ISSN(Print); 1119944X

http://journal.aesonnigeria.org

http://www.ajol.info/index.php/jae

Email: editorinchief@aesonnigeria.org

and initiative to apply strict biosecurity measures on their farms. An earlier study conducted in Nigeria shows that, keeping flocks indoors without knowing the basic principles of biosecurity could actually expose humans to flocks, resulting in a higher risk of infection to the flock and humans (zoonosis) (Alhaji and Odetokun, 2011). Restricting people's movement in the farms limits the risk of introducing infectious agents into flocks. This is consistent with the study of Alhaji and Odetokun (2011) and Henning et al, (2009). Shama (2010) reports that people who come into poultry houses can introduce very serious diseases.

Poultry farmers provided foot dip with disinfectant which is contrary to the finding of Ameji et al. (2012) in Kogi State, Nigeria and Ambarawati et al. (2010) in Bali, Melbourne Australia where poultry farmers had poor sanitation with the majority of farmers not having footbath. According to Mccrea and Bradley (2008) sanitation is crucial in poultry houses in other to eliminate disease agents. Disinfectant footbaths may help to decrease the dose of organisms on boots. To maintain efficiency, there is need to change the disinfectant on regular basis. These have serious implications in curtailing the spread of contagious poultry diseases by people as well as being of public health importance regarding several poultry diseases.

Adequate cleaning of feeding and drinking trough is important as observed in this study. Poultry farmers are expected to have periodic clean-out, clean-up and disinfection of houses and equipment, at least once in every production cycle of poultry birds (Banshi, 2010). Shane (1995) noted that, effective cleaning and disinfecting methods can substantially decrease disease transmission by reducing pathogen in the environment below infection level. Similarly, Sharma (2010) stated that clean poultry farm will reduce foul smelling to neighbors and disease spread. Poultry manure is good for agricultural product. Organic farming can be boosted along with poultry farming which will ultimately lead to sustainable development and clean environment. Dead carcasses should be buried with due care so that they will not contaminate soil and water.

Poultry farmers in the study area isolated and quarantined sick birds, recognized disease signs and reported such to veterinarians for urgent attention. This is consistent with the suggestion of Mccrea and Bradley (2008) who noted that procedures should be developed for emergency action if a bird in the flock falls ill, is injured, or is found dead. They further reiterated that sick or injured birds should immediately be placed in a quarantine area. The prompt report of sickness in the poultry farms by respondents shows that they are aware of the implications of diseases in the farm. This is a good practice as it may help to improve the condition of birds which may lead to increased production.

\section{Socio-Economic Factors Influencing Farmers' Biosecurity Practices}

Variables that had significant positive influence $\left({ }^{*} p \leq 0.05\right)$ on biosecurity practices were: age (0.327), farming experience (0.278), and farm income (0.409). Use of battery cage system $(-0.358)$ and use of deep litter combined with battery cage systems (-0.536) had a negative influence on the use of biosecurity practices. Therefore, the null hypothesis was rejected for these variables. The overall regression model was significant $(F=7.52$; $\mathrm{P} \leq 0.05$ accounting for $64 \%$ (adjusted $\mathrm{R}$ squared) of the variance. 
Creative commons User License: CC BY-NC-ND

Abstracted by: EBSCOhost, Electronic Journals Service (EJS), Google Scholar, Directory of Open Access Journals (DOAJ), Journal Seek, Scientific Commons,

Food and Agricultural Organization (FAO), CABI and Scopus

\author{
Journal of Agricultural Extension \\ Vol. 21 (3) October, 2017 \\ ISSN(e): 24086851; ISSN(Print); 1119944X \\ http://journal.aesonnigeria.org \\ http://www.ajol.info/index.php/jae \\ Email: editorinchief@aesonnigeria.org
}

The observation that use of battery cage system and use of deep litter combined with battery cage systems had a negative influence on biosecurity practices may be attributed to the fact that, in the battery cage system, birds hardly come in contact with faeces and equipment. This practice may therefore reduce disease incidence in farms that use this system. Therefore, the farmer may not find it necessary to practice biosecurity since he/she may seldom experience disease outbreak in the farm. According to Brandy (2012), using battery cage is important because it is easy to control diseases and parasites. This control can be done without using drugs, which is important to many consumers today who are concerned about drug residues in their food. 
Creative commons User License: CC BY-NC-ND

Abstracted by: EBSCOhost, Electronic Journals Service (EJS),

Google Scholar, Directory of Open Access Journals (DOAJ),

Journal Seek, Scientific Commons,

Food and Agricultural Organization (FAO), CABI and Scopus
Journal of Agricultural Extension

Vol. 21 (3) October, 2017

ISSN(e): 24086851; ISSN(Print); 1119944X

http://journal.aesonnigeria.org

http://www.ajol.info/index.php/jae

Email: editorinchief@aesonnigeria.org

Table 4: Influence of socioeconomic characteristics on biosecurity practices

\begin{tabular}{|c|c|c|c|c|}
\hline \multirow[b]{2}{*}{ Model } & \multicolumn{2}{|c|}{$\begin{array}{c}\text { Unstandardized } \\
\text { Coefficients }\end{array}$} & \multirow{2}{*}{$\begin{array}{c}\text { Standardized } \\
\text { Coefficients } \\
\text { Beta }\end{array}$} & \multirow[b]{2}{*}{$\mathrm{T}$} \\
\hline & $\mathrm{B}$ & Std. Error & & \\
\hline (Constant) & 14.677 & 2.289 & & 6.412 \\
\hline Age & 0.069 & 0.031 & $0.327^{\star}$ & 2.204 \\
\hline Sex & 0.275 & 0.405 & 0.076 & 0.679 \\
\hline Farming experience & 0.121 & 0.046 & $0.278^{*}$ & 2.653 \\
\hline Years spent in school & 0.055 & 0.064 & 0.138 & 0.858 \\
\hline $\begin{array}{l}\text { Membership of social } \\
\text { organization }\end{array}$ & -0.095 & 0.047 & -0.271 & -2.018 \\
\hline Farm income & 1.834E-7 & 0.000 & $0.409^{*}$ & 2.794 \\
\hline Source of credit & 0.166 & 0.224 & 0.087 & 0.744 \\
\hline Household size & 0.161 & 0.090 & 0.253 & 1.780 \\
\hline Flock size & 0.000 & 0.000 & -0.168 & -0.976 \\
\hline Deep litter system & 0.191 & 1.010 & 0.034 & 0.189 \\
\hline $\begin{array}{l}\text { Use of battery cage } \\
\text { system }\end{array}$ & -4.326 & 1.640 & -0.358 & -2.639 \\
\hline $\begin{array}{l}\text { Use of deep litter and } \\
\text { battery cage systems }\end{array}$ & -3.038 & 0.825 & -0.536 & -3.684 \\
\hline
\end{tabular}

The use of biosecurity measures increases as age, farming experience, farm income and number of social organisation belong to increases. Belonging to a social group enhances social capital, thus allowing trust, idea and information exchange (Mignouna et al., 2011). Farmers within a social group learn from each other the benefits and use of a new technology. Uaiene et al. (2009) suggests that social network effects are important for individual decisions, and that, in the particular context of agricultural innovations, farmers share information and learn from each other. Hence farmers who belong to social organizations will learn more about biosecurity measures and therefore the likely hood to adopt them. Use of biosecurity measures increases as age increases. Langy and Mekura (2005) reported that older farmers have higher accumulated capital, more contacts with extension workers, are better preferred by credit institutions and larger family size, all of which may enhance their adoption and use of technologies such as biosecurity measures than younger farmers. Older farmers are assumed to have gained knowledge and experience over time and are better able to evaluate technology information than younger farmers (Mignouna et al, 2011; Kariyasa and Dewi 2011). On the contrary, age has been found to have a negative relationship with adoption of technology. Mauceri et al. (2005) found out that as farmers grow older, there is an increase in risk aversion and a decreased interest in long-term investment in the farm. On the other hand, younger farmers are typically less risk-averse and are more willing to try new technologies.

Years of experience also had significant influence on biosecurity practices. Farmers with more experience would be more efficient, have better knowledge of biosecurity practices and are thus, expected to run a more efficient and profitable enterprise (Oluwatayo et al., 2008). The findings of Onyebinama (2004) states that previous 
Creative commons User License: CC BY-NC-ND

Abstracted by: EBSCOhost, Electronic Journals Service (EJS), Google Scholar, Directory of Open Access Journals (DOAJ), Journal Seek, Scientific Commons,

Food and Agricultural Organization (FAO), CABI and Scopus
Journal of Agricultural Extension

Vol. 21 (3) October, 2017

ISSN(e): 24086851; ISSN(Print); 1119944X

http://journal.aesonnigeria.org

http://www.ajol.info/index.php/jae

Email: editorinchief@aesonnigeria.org

experience in farm business management enables farmers to set realistic time and cost targets, allocate, combine and utilize resources efficiently and identify production risks. As farmers' years of farming experience increases the probability of farmers having experience in disease management and other farm practices increases. This could be because with more experience, the farmer is likely to manage the farm better and make more informed decisions. It is expected that the more the experience farmers have in poultry production, the more the farmers might adopt biosecurity measures and use them effectively. This experience may be gained through learning by doing by the farmers themselves, by observing what other farmers are doing, or from training provided by relevant institutions. Also, the effect of farm income cannot be over emphasized. High income guarantees farmers' access to biosecurity measures.

Sex, flock size, household size and education had no significant influence on the use of biosecurity measures. The observation that education has no significant influence on the use of biosecurity measures is surprising since it is expected that high literacy level will help farmers analyse and understand the rationale of using biosecurity measures. Mignouna et al., (2011); Lavison (2013) and Namara et al., (2013) reported that education of the farmer is assumed to have a positive influence on farmers' decision to adopt new technology. Education of a farmer increases his ability to obtain; process and use information relevant to adoption of a new technology. This is because higher education influences respondents' attitudes and thoughts making them more open, rational and able to analyze the benefits of the new technology (Waller et al., 1998). However, some authors have reported insignificant or negative effect of education on the rate of technology adoption (Khanna, 2001; Banerjee et al., 2008; Samiee et al., 2009). The finding that sex has no significant influence on the use of biosecurity measures is contrary to the finding of Obisesan (2014) who found that sex had a significant and positive influence on adoption of improved cassava production in Nigeria. The fact that household size had no significant effect on biosecurity practices of poultry farmers is inconsistent with the finding of Akintunde and Adeoti (2014). High number of persons in the household may increase the quest of increasing production to enable the farmer cater for the needs of his/her members. It is therefore expected that high household size will increase use of biosecurity measures. On the contrary, high household size may provide adequate labour to the farm which may lead to reduced disease outbreak.

\section{Conclusion and Recommendations}

Age, farming experience, membership of social organisation, farm income and use of battery cage system of production were found to have significant influence on biosecurity measures adopted by farmers. Although farmers' use of biosecurity measures was high, there is need to educate them on the importance of adhering to strict biosecurity measures in their farmers. Also, government, policy makers, extension agents, NGOs and related organizations should provide the farmers with subsidy/incentives that will help them build a strong financial base to help them upgrade their farms with sound biosecurity measures for increased production in order to earn more as well as adhere strictly to sound biosecurity measures. 
Creative commons User License: CC BY-NC-ND

Abstracted by: EBSCOhost, Electronic Journals Service (EJS),

Google Scholar, Directory of Open Access Journals (DOAJ),

Journal Seek, Scientific Commons,

Food and Agricultural Organization (FAO), CABI and Scopus
Journal of Agricultural Extension

Vol. 21 (3) October, 2017

ISSN(e): 24086851; ISSN(Print); 1119944X

http://journal.aesonnigeria.org

http://www.ajol.info/index.php/iae

Email: editorinchief@aesonnigeria.org

\section{References}

Abdelqader A, Wollny CB, Gauly M (2007). Characterization of local chicken production systems and their potential under different levels of management practice in Jordan. Trop Anim Health Prod, 39(3):155-164.

Abdu, P.A. (2007). Manual of Important Poultry Diseases in Nigeria (2nd edition). MacChin Multimedia Designers, Samaru-Zaria. Pp 1 - 100.

Adene D.F. \& Oguntade, A.E. (2006). The structure and importance of the commercial and rural based poultry industry in Nigeria. FAO (Rome) study, October, 2006. Pp 1-70.

Adewole, S.O. (2012). The efficacy of drugs in the treatment of coccidiosis in chicken in selected poultries. Acad. Res. Int., 2:20-24.

Alhaji, N.B., Odetokun, I.A. (2011). Assessment of biosecurity measures against Highly Pathogenic Avian Influenza risks in small-scale commercial farms and free-range poultry flocks in the Northcentral Nigeria. Transbound Emerg Dis, 58(2):157-161.

Ambarawati, I.G., K. Bugie and P. Ian, (2010). Farmer investment into bio-security on broiler and layer farms; In Bali, Melbourne Australia, pp: 12.

Ameji N.O., Abdu P.A., Sa'idu L. \& Isa-Ochepa M. (2012). Knowledge of poultry diseases, biosecurity and husbandry practices among stakeholders in poultry production in Kogi State, Nigeria. Sokoto Journal of Veterinary Sciences, 10 (2):26-31.

Asfaw, A. \& Admassie, A. (2004). The role of education in the adoption of chemical fertilizer under different socio-economic environments in Kenya. Agricultural Economics, 30, 215-228.

Avian Influenza Control Programme (AICP) (2008). Highly pathogenic avian influenza surveillance and recent updates. Bird flu Watch, Vol.1 No.1.August, 2008, Pp 10.

Ayodele J. (2016). Poultry (Chicken) farming: Advantage of using battery cages. Available at https://johnayodele.wordpress.com/2011/02/23/what-a-beginnershould-know-to-succeed-in-poultry-farming Accessed 16/05/16.

Badubi SS, Ravindran V, Reid J (2004). A survey of small-scale broiler production systems in Botswana. Trop Anim Health Prod, 36(8):823-834.

Bamire, A. S., Fabiyi, Y. L., Manyong, B. (2002). Adoption pattern of fertilizer technology among farmers in the ecological zones of south western Nigeria: a Tobit analysis. Australian Journal of Agricultural Research, 5, 901-910.

Banerjee, B., Martin, S., Roberts, R., Larkin, S., Larson, J., Paxton, K., English, B., Marra, M., and Reeves, J. (2008). A binary logit estimation of factors affecting adoption of GPS guidance systems by cotton producers; Journal of agricultural and applied economics 40(1): 345-355.

Banshi, S. (2010). Poultry production, management and bio-security measures. The Journal of Agriculture and Environment, 11:120-125.

Bell JG (2009). Factors limiting production efficiency and profitability from smallholder poultry production. Worlds Poult Sci J, 65:207-210. 
Creative commons User License: CC BY-NC-ND

Abstracted by: EBSCOhost, Electronic Journals Service (EJS),

Google Scholar, Directory of Open Access Journals (DOAJ),

Journal Seek, Scientific Commons,

Food and Agricultural Organization (FAO), CABI and Scopus
Journal of Agricultural Extension

Vol. 21 (3) October, 2017

ISSN(e): 24086851; ISSN(Print); 1119944X

http://journal.aesonnigeria.org

http://www.ajol.info/index.php/jae

Email: editorinchief@aesonnigeria.org

Biswas PK, Uddin GM, Barua H, Roy K, Biswas D, Ahad A, Debnath NC (2008). Survivability and causes of loss of broody-hen chicks on smallholder households in Bangladesh. Prev Vet Med, 83(3-4):260-271.

Branckeart, R.D.S., Gavira, L., Jallade, J. and Seiders, R.W. (2000). Transfer of technology in poultry production for developing countries. Sustainable Development Department, Food and Agriculture Organization of the United Nations, Rome, Italy.

Brandy, R. (2012). The future of confinement housing for egg-laying hens. Farm animal welfare news. BCSPCA Farm Sense.

Duncan lan J.H. (2001). The pros and cons of cages. World Poultry Science, 57: 381-390.

Ekong, E.E. (2010). Introduction to Rural Sociology 3rd Ed. Uyo: Dove Educational Publishers.

Food and Agriculture Organisation (2005). Agricultural Knowledge and Information Systems for Rural Development (AKIS/RD). Strategic Vision and Guiding Principles.

FAO, (2010). Small holder poultry production livelihood food security and sociocultural significance. FAO smallholder poultry production paper No 4, Rome.

Farooq, M., Durrani, F.R., Faisal, S., Asghar, A. and Khurshid, A. (2000). Incidence of infectious bursal disease among birds submitted to a diagnostic laboratory in NWFP, Pakistan. Pak. Vet. J., 20:77-80.

Henning, K.A., Henning, J., Morton, J., Long, N.T., Ha, N.T., Meers, J. (2009). Farmand flock-level risk factors associated with Highly Pathogenic Avian Influenza outbreaks on small holder duck and chicken farms in the Mekong Delta of Viet Nam. Prev Vet Med, 91(2-4):179-188.

Ison, A.J., Spiegle S.J., Morishita, T.Y. (2012). Predators of poultry. http://ohiolineosu.edu/vme-fact/0022.html.

Jordan FTW (1990). Poultry Diseases (3rd edition), English Language Book Society/ Balliere Tindall, 24-28 Oval Road, London. Pp 1- 467.

Kariyasa, K., Dewi, A. (2011).Analysis of Factors Affecting Adoption of Integrated Crop Management Farmer Field School (Icm-Ffs) in Swampy Areas. International Journal of Food and Agricultural Economics, 1(2): pp 29-38

Khanna, M. (2001). "Sequential Adoption of Site-Specific Technologies and Its Implications for Nitrogen Productivity: A Double Selectivity Model." American Journal of Agricultural Economics, 83(1):35-51.

Langy, A. and Mekura, M. (2005). Modelling agricultural technology adoption using the software STAT. A paper presented at a training course organized by CIMMUT-ALP for its NARS partners in Southern Africa on econometric application of modelling technologies.

Lavison, R. (2013). Factors Influencing the Adoption of Organic Fertilizers in Vegetable Production in Accra (MSc Thesis). Accra Ghana. Loevinsohn M, Sumberg J, Diagne

Maikasuwa M.A. and Jabo M.S.M. (2011). Profitability of Backyard Poultry Farming in Sokoto Metropolis, Sokoto State, North-West, Nigeria Nigerian Journal of Basic and Applied Science 19 (1): 111- 115 ISSN 0794-5698. Available online at http://www.ajol.info/index.php/njbas/index. 
Creative commons User License: CC BY-NC-ND

Abstracted by: EBSCOhost, Electronic Journals Service (EJS),

Google Scholar, Directory of Open Access Journals (DOAJ),

Journal Seek, Scientific Commons,

Food and Agricultural Organization (FAO), CABI and Scopus
Journal of Agricultural Extension

Vol. 21 (3) October, 2017

ISSN(e): 24086851; ISSN(Print); 1119944X

http://journal.aesonnigeria.org

http://www.ajol.info/index.php/jae

Email: editorinchief@aesonnigeria.org

Maningas, R. V., Perez, V. O., Macaraig, A. J., Alesna, W. T., and Villagonzalo J. (2005). "Electronic Information Dissemination through the Farmers' Information and Technology Services (FITS)/Techno Pinoy Program. Bringing Information and Technology within the Reach of the Farmers." from http://jsai.or.jp/afita/afita-conf/2000/part08/p231.pdf, 2000.

Mauceri, M., Alwang, J., Norton, G. Barrera, V. (2005). Adoption of Integrated Pest Management Technologies: A Case Study of Potato Farmers in Carchi, Ecuador; Selected Paper prepared for presentation at the American Agricultural Economics Association Annual Meeting, Providence, Rhode Island, July 24-27, 2005

Mccrea, B. A. \& Bradley F. A. (2008). Biosecurity for poultry at community farms. University of California Division of Agriculture and Natural Resources Publication 8280. ANR CS Web site, http://anrcatalog.ucdavis.edu

Mignouna, B., Manyong, M., Rusike, J., Mutabazi, S., \& Senkondo, M. (2011). Determinants of Adopting Imazapyr-Resistant Maize Technology and its Impact on Household Income in Western Kenya: AgBioforum, 14(3), 158-163. Hall, B. and Khan, B. (2002) Adoption of new technology. New Economy Handbook.

Mohamadou, F.J., Christine, J. \& John, I. (2010). Financial costs of disease burden, morbidity and mortality from priority livestock disease in Nigeria. The World Bank Paper, International Livestock Research Institute (ILRI), Nigeria.

Musa, I.W., Sai'du, L. and Abalaka, E.S. (2012). Economic impact of recurrent outbreaks of gumboro disease in a commercial poultry farm in Kano, Nigeria. Asian Journal of Poultry Science, 6:152-159.

Namara, E., Weligamage, P., Barker, R. (2003). Prospects for adopting system of rice intensification in Sri Lanka: A socioeconomic assessment. Research Report 75. Colombo, Sri Lanka: International Water Management Institute.

National Bureau of Statistics (NBS) (2009). Social Statistics in Nigeria.

Obisesan, A. (2014). Gender Differences in Technology Adoption and Welfare Impact among Nigerian Farming Households, MPRA Paper No. 58920

Oluwatayo, I.B., Sekumade, A.B., Adesoji, S.A. (2008). Resource use efficiency of maize farmers in rural Nigeria, Evidence from Ekiti State. World Journal of Agricultural Science, 4(1):91-99.

Onyebinama, U.A. (2004). Farm business management for smallholder farm firms in Nigeria. Owerri Alphabet Nigeria Publishers, Nigeria; 2004.

Samiee, A., Rezvanfar, A., Faham, E. (2009). Factors affecting adoption of integrated pest management by wheat growers in Varamin County, Iran: African Journal of Agricultural Research 4(5); 491-497

Shane, B. (1995). Decontamination of housing and equipment in bio-security in the poultry industry. American association of avian pathologist, University of Pennsylvania, New Boltan Center, Kennet Squre. PA. pp: 120.

Sharma, B. (2010). Poultry production management and bio-security measures. J. Food Agric. and Environ, 1:122.

Sonaiya, E.B., Swan, S.E.J. (2004). Small-scale poultry production. Rome: FAO. 
Creative commons User License: CC BY-NC-ND

Abstracted by: EBSCOhost, Electronic Journals Service (EJS),

Google Scholar, Directory of Open Access Journals (DOAJ),

Journal Seek, Scientific Commons,

Food and Agricultural Organization (FAO), CABI and Scopus

\author{
Journal of Agricultural Extension \\ Vol. 21 (3) October, 2017 \\ ISSN(e): 24086851; ISSN(Print); 1119944X \\ http://journal.aesonnigeria.org \\ http://www.ajol.info/index.php/jae \\ Email: editorinchief@aesonnigeria.org
}

Uddin I.O., Enwelu I.A. and Igbokwe E.M. (2015). Influence of socioeconomic characteristics of farmers on knowledge of herbicide use in Edo State, Nigeria. Life Sciences International Research Journal, vol. 2(1), pp 301-307.

Uaiene, R., Arndt, C., Masters, W. (2009) Determinants of Agricultural Technology Adoption in Mozambique. Discussion papers No. 67E

United State Agency for International Development (USAID)/Stop Al (2009). Biosecurity for farms and markets in Nigeria. Trainer guide, January 12-23, 2009, Kaduna, Nigeria.

Usman, B.A. \& Diarra, S.S. (2008). Prevalent diseases and mortality in egg type layers: An overview. International Journal of Poultry Science, 7:304-310.

Uzokwe U.N. and EA Bakare, (2013). The Effects of climate variability on poultry production in Ose Local Government Area of Ondo State, Nigeria: Socioeconomic characteristics and perceptions of farmers. Inter J. Agric. Biosecurity, 2(1): 39-44.

Vidanapathirana, N.P. (2012). Agricultural information systems and their applications for development of agriculture and rural community, a review study, pp 1-14. http://iris.im.uu.se/wp-uploads/2012/08/iris2012 submission 27.pdf.

Accessed 2/10/2015 